African Crop Science Journal by African Crop Science Society is licensed under a Creative Commons Attribution 3.0 Uganda License. Based on a work at www.ajol.info/ and www.bioline.org.br/cs DOI: http://dx.doi.org/10.4314/acsj.v24i4.3

\title{
APPLICATION OF MORPHO-ANATOMICAL TRAITS OF MAIZE PLANT TO QUALITY CONTROL AND QUALITY ASSURANCE IN MAIZE SEED SYSTEM
}

\author{
I.Y.A. MONIR, J.P. SSERUMAGA ${ }^{1}$, S.B. AYESIGA, S. KATUROMUNDA and G. ASEA ${ }^{1}$ \\ College of Agricultural and Environmental Sciences, Department of Agricultural Production, \\ Makerere University, P. O. Box 7062 Kampala, Uganda \\ ${ }^{1}$ Cereals Program, National Agricultural Research Organization, National Crops Resources Research Institute, \\ Namulonge, P. O. Box 7084 Kampala, Uganda \\ Corresponding author: j.serumaga@gmail.com
}

(Received 8 February, 2016; accepted 18 August, 2016)

\begin{abstract}
Good seed quality can be obtained through control of the entire seed production process. There are emerging issues in the seed sector due to seed quality in market. In many countries seed and planting materials available to farmers are often of insufficient quality, thus undermining the potential performance of crops. The objective this study was to use morpho-anatomical traits to determine the levels of maize hybrid seed purity on the market in Uganda. A total of 120 samples of four popular commercial maize hybrid were collected from agro-dealers in 13 districts, representing 3 seed companies' distribution network. The samples were planted and evaluated based on their descriptors, using an Alpha Lattice Design, with two replications at the National Crops Resources Research Institute (NaCRRI), Namulonge. Data were collected for 33 morpho-anatomical traits. Results showed significant $(\mathrm{P}<0.05)$ differences within hybrids, and sources of seed among districts. Among the test materials, only Longe $9 \mathrm{H}$ had no significant $(\mathrm{P}<0.05)$ difference within traits but others had some levels of significant $(\mathrm{P}<0.05)$ differences. The principal component analysis of quantitative traits resulted in four components for each variety, with the explanation total of $53.3 \%$ for Longe $6 \mathrm{H}, 51.1 \%$ for Longe $7 \mathrm{H}$, and $92.8 \%$ for Longe $9 \mathrm{H}$ and $39.1 \%$ for Longe $10 \%$. There were varying levels of contamination of commercial hybrids based on morphoanatomical traits diversity within hybrids, compared to their descriptors for the traits evaluated. Hence, there is need to strengthen the quality control sub-sector for improved productivity at farmer levels.
\end{abstract}

Key Words: Diversity, Longe, seed, Uganda, Zea mays

\section{RÉSUMÉ}

Des semences de bonne qualité peuvent être obtenues en exerçant un control systématique sur chacun des maillons du système de production semencière. Le secteur semencier connaît de plus en plus de difficultés, et ceci en raison de la qualité des semences sur le marché. Dans plusieurs pays, les semences disponibles pour les producteurs sont souvent de qualité non satisfaisante, reduisant ainsi la performance des cultures. L'objectif de l'étude était de se servir des caractères morpho-anatomiques afin de determiner le niveau purité des semences de maïs hybride sur le marché semencier en Ouganda. Au total 120 échantillons des quatre variétées commerciales populaires de maïs hybride ont été collectés chez les distributeurs de semences dans 13 districts, représentant les réseaux de distribution de 3 compagnies semencières. Les échantillons ont été semés et évalués en se basant sur leurs descripteurs. Le dispositive expérimental Alpha Lattice a été utilisé, avec deux répétitions à l'institut national de recherche des ressources culturales (NaCRRI), Namulonge. Les données de 33 caractères morphoanatomiques ont été collectées. Les résultats ont montré des differences significatives $(\mathrm{P}<0,05)$ ont été observées parmi les hybrides, ainsi que les sources des semences au sein des districts. Parmi les matériels testés, seul Longe 
$9 \mathrm{H}$ n'avait exhibé aucune difference significative $(\mathrm{P}<0,05)$ des caractères évalués, mais certains ont des differences significatives à $(\mathrm{P}<0,05)$. l' analyse en composntes principales des traits quantitatifs a montré quatre composantes pour chaque variété, avec l'ensemble de ces composantes expliquant 53,3\% de la variation totale pour Longe $6 \mathrm{H}$, $51,1 \%$ pour Longe $7 \mathrm{H}, 92,8 \%$ pour Longe $9 \mathrm{H}$ et $39,1 \%$ pour Longe $10 \%$. Les niveaux de contamination étaient variables, suggérant la nécessité de renforcer le sous-secteur de control de qualité en vue d'une meilleure productivité au niveau des producteurs.

Mots Clés: Diversité, Longe, semence, Ouganda, Zea mays

\section{INTRODUCTION}

Development of seed supply systems is a prerequisite for ensuring food security, especially in Sub-Saharan Africa (SSA) (FNSU-UDS, 2011). A regulated seed system is crucial for amplified production and productivity of maize, a highly demanded cereal crop in SSA. Formal and informal seed production and supply systems are recognised as the two systems of seed production and supply in SSA (Mubangizi et al., 2012).

The formal seed production and supply system in countries like Uganda generate highquality seeds of genetically improved hybrids (Barnett et al., 2011). It aims at enabling farmers access seed of high quality, as well as being free from seed-borne pathogens. Production of high quality seeds is accomplished by regular and rigorous monitoring and supervision of the seed crop in the field, and after harvest during processing and packaging, as well as confirmation of quality through laboratory tests before sale to farmers. Thus, seeds are expected to have better yield potential than seeds from the informal seed sector (farmer-saved and community-based seed systems).

Good quality seed is the cheapest input in crop production chain, and the key to agriculture development. The status of a crop largely depends on the seed materials used for sowing, provided other conditions of weather and nutrients are kept optimum (Mrutu, 2015). It is estimated that good quality seeds of improved hybrids can contribute about 20 to $25 \%$ increase in yield (Beshir, 2011, Mrutu, 2015). Poor access to quality seeds by farmers is a major crop production constraint in Uganda.

Despite all efforts to ensure that high quality seeds are available to farmers, the Uganda seed sector is characterised by counterfeit seeds, which leads to an inability of farmers to exploit the full potential of improved hybrids (Mubangizi et al., 2012). Barnett et al. (2011) reported that $40 \%$ of seed available on the market in Uganda is counterfeit. The presence of counterfeit seeds on the market reduces farmers' confidence in the seed supply chain, and in turn, affects the adoption of improved hybrids. In order for farmers to obtain high grain yields, it is important that the purity of seed be maintained at all levels, right from breeder seed up to certified seed supplied on the market.

Uganda's formal seed sector focuses on regulation in all stages of production, from breeder seed production, basic and certified seed bulking, processing, certification and seed distribution. Most of the crop hybrids on the market in Uganda have been developed and/or released by the public sector, through the National Agricultural Research Organization (NARO). Also, private sectors have commercialised a number of their own hybrids, although the process of variety testing for release, quality control in seed production and regulation of the seed market are all done by the National Seed Certification Service (NSCS) as provided for in the law (Plant and Seed Act, 2006).

As a result, the public sector has been responsible for most of the early generation seed production; while most of the small to medium scale seed companies concentrate on production of basic and certified seed. In addition, the public sector concentrates much on less commercial crops such as millet, rice, and cowpeas. Maize is the major crop commodity for private sector seed commercialisation, however, limited amounts of other crops such as sunflower, sesame, sorghum, beans, and vegetables are being commercialised. Seed production by most of the seed companies is primarily through contract farmers while 
distribution and sales of seeds are effected through the agro-dealer network.

Currently, in Uganda, seed crop certification for purity and variety distinctness by the National Seed Certification Service (NSCS), is based on phenotypic/morpho-anatomical traits as provided for in their description. The phenotypic diversity is an important morpho-anatomical traits that reveals important features for verification of variety distinctness. During the quality control of seeds, most of the quality components are based on morpho-anatomical traits. These characters have been recognised to constitute universally acknowledged descriptors for varietal characterisation and inaugurating the distinctness, uniformity and stability (DUS) of crops in Plant Variety Protection (PVP) system (Begum and Kumar, 2011; Chanda et al., 2014).

The varietal traits used in DUS also accounts for the plasticity of phenotypic appearances and, thus are proficient for comparing hybrids (Law et al., 2011). Despite the drawback of morphoanatomical traits being expensive and affected by the environment, they are still very important for breeding high yielding genotypes and discriminations (Hung et al., 2012; Law et al., 2011; Smýkal et al., 2008). Morpho-anatomical traits are, therefore, important for variety release, maintenance and seed certification.

The objective this study was to use morphoanatomical traits to determine the levels of maize hybrid seed purity on the market in Uganda.

\section{MATERIALS AND METHODS}

The study was conducted at the National Crops Resources Research Institute (NaCRRI), Namulonge (0.5297 latitude, 32.6025 longitude, $1150 \mathrm{~N}$ elevation (masl) ) in Central Uganda. In 2013/14, a total of 120 samples of four maize hybrids comprising 116 samples were collected randomly from agro-dealers in 13 districts and four samples from seed companies (reference samples) were used in the study (Table 1). Among these comprised of four popular maize hybrids maize hybrids namely; Longe $6 \mathrm{H}$, Longe $7 \mathrm{H}$, Longe $9 \mathrm{H}$ and Longe $10 \mathrm{H}$ from three seed companies (Seed Co A, Seed Co B, and Seed Co C. in Uganda. Entries (herein referred to as samples) were randomised in Breeding Management System (The IBP Breeding Management System Version 3.0.8) and planted using an Alpha Lattice experimental design, which was a four by thirty simple lattice, with two replications. Each entry was planted in tworow plots of 5 metres length and $0.75 \mathrm{~m}$ apart. The hills were spaced 0.25 metres apart. Two seeds per hill were planted and later thinned at three weeks after emergence to one plant per hill to give a plant population of 53,333 plants per hectare. Standard agronomic and cultural practices were performed as recommended.

During the growing period, data on several morpho-anatomical traits were collected. For each source, $10 \times 10-\mathrm{m}$ rows were planted, data on morphological traits were collected according to procedures and guidelines outlined by the International Union for the Protection of New Hybrids of Plants (UPOV, 2009) (Table 2).

The mean values for 33 morphological characters and scaling values were used to assess the dissimilarity between the reference materials from Seed Companies and samples from Agrodealers. The matrix of all quantitative traits was first standardised before calculating the Euclidean similarity distance matrix among the hybrids.

For each trait, an individual analysis of variance (ANOVA) was conducted using GenStat $12^{\text {th }}$ Edition.

Principal Component Analysis (PCA) was performed on the phenotypic correlation matrix of the adjusted means, so as to estimate the relationships between the traits (IgnjatoviæMiciæ et al., 2013), using MINITAB 14. Also, the qualitative data were subjected to PCA to identify traits that are most discriminatory among hybrids sources. A dendrogram was constructed using Ward method (Ward, 1963) to provide a general visualisation of the relationship between hybrids based on quantitative traits using GenStat $12^{\text {th }}$ Edition.

\section{RESULTS}

Analysis of variance. Longe $10 \mathrm{H}$ had the most traits with significant differences (time of anthesis, density of spikelets, time of silk emergence, length of the main axis above lowest 
TABLE 1. Samples used and their origins in a study on maize seed quality control in Uganda

\begin{tabular}{|c|c|c|c|c|}
\hline Region & District & Hybrids & Seed companies & Hybrids \\
\hline \multirow[t]{13}{*}{ East } & \multirow[t]{4}{*}{ Soroti } & Longe 9H & Company A & Longe $7 \mathrm{H}$ \\
\hline & & Longe $7 \mathrm{H}(4)$ & & Longe $6 \mathrm{H}$ \\
\hline & & Longe $6 \mathrm{H}(3)$ & & Longe $9 \mathrm{H}$ \\
\hline & & Longe $10 \mathrm{H}(8)$ & Company B & Longe $7 \mathrm{H}$ \\
\hline & Kumi & Longe $10 \mathrm{H}(2)$ & Company C & Longe $10 \mathrm{H}$ \\
\hline & \multirow[t]{2}{*}{ Bukedea } & Longe 6H & & \\
\hline & & Longe $7 \mathrm{H}$ & & \\
\hline & \multirow[t]{4}{*}{ Iganga } & Longe $6 \mathrm{H}$ & & \\
\hline & & Longe $7 \mathrm{H}(3)$ & & \\
\hline & & Longe $9 \mathrm{H}$ & & \\
\hline & & Longe 10H & & \\
\hline & Bugiri & Longe 10H & & \\
\hline & Mbalala & Longe $10 \mathrm{H}$ & & \\
\hline \multirow[t]{2}{*}{ North } & \multirow[t]{2}{*}{ Lira } & Longe $10 \mathrm{H}(2)$ & & \\
\hline & & Longe $6 \mathrm{H}(2)$ & & \\
\hline \multirow[t]{6}{*}{ West } & \multirow[t]{2}{*}{ Masindi } & Longe 6H (8) & & \\
\hline & & Longe $10 \mathrm{H}(4)$ & & \\
\hline & \multirow[t]{2}{*}{ Hoima } & Longe $6 \mathrm{H}$ & & \\
\hline & & Longe $10 \mathrm{H}(2)$ & & \\
\hline & Bweyale & Longe 6H & & \\
\hline & Kigumba & Longe $6 \mathrm{H}$ & & \\
\hline South-west & Muhabura & Longe $6 \mathrm{H}$ & & \\
\hline Central & Masaka & Longe $10 \mathrm{H}$ & & \\
\hline
\end{tabular}

Seed Companies are identified by $A, B, C$ to maintain anonymity

side branch, length of peduncle, ear length) (Table 3 ). This was followed by Longe $7 \mathrm{H}$ (time of anthesis and anthocyanin coloration of brace roots). Lastly was Longe $6 \mathrm{H}$ (attitude of blade and anthocyanin colouration of base of glume were significant) (Table 3). Among the test materials, only Longe $9 \mathrm{H}$ had no significant difference within traits.

Principal component analysis. Principal component analysis (PCA) was used to determine the key traits which can be used to differentiate within the same variety. The PCA of the traits resulted in the first four components for each variety, with the highest eigenvalue. The four PCs explained a total of 53.3\% for Longe $6 \mathrm{H}$ (Table 4 ), $51.1 \%$ for Longe $7 \mathrm{H}$ (Table 5), $92.8 \%$ for Longe 9H (Table 6), and $39.1 \%$ for Longe $10 \mathrm{H}$ (Table 7). Longe 9H, which had the highest PCs value explaining the phenotypic variation showed that the first component accounted for $40.7 \%$ of the total variation. The second, third and four 
TABLE 2. The traits that were collected using visual scoring method

\begin{tabular}{|c|c|c|}
\hline Trait & Property & Scale \\
\hline Anthocyanin coloration (an col) & 2 Leaves unfolded & Score (1-9) \\
\hline Shape of tip (shape t) & 4 Leaves unfolded & Score $(1-5)$ \\
\hline Angle between blade and stem (angle bs) & Leaf just above upper ear & Score (1-9) \\
\hline Attitude of blade (at of $\mathrm{b}$ ) & Leaf just above upper ear & Score (1-9) \\
\hline Degree of zig-zag & Beginning of anthesis & Score (1-3) \\
\hline Anthocyanin coloration of brace roots (an col br) & Halfway anthesis & Score $(1-9)$ \\
\hline Time of anthesis ( $\tan )$ & Middle third of main axis & Score (1-9) \\
\hline Anthocyanin coloration of base of glumes (an col bg) & Middle third of main axis at base of glumes & Score $(1-9)$ \\
\hline $\begin{array}{l}\text { Anthocyanin coloration of glumes excluding base } \\
\text { (an col gex) }\end{array}$ & Middle third of main axis & Score (1-9) \\
\hline Anthocyanin coloration of anthesis (an col anth) & Middle third of main axis on fresh anthesis & Score (1-9) \\
\hline Density of spikelets (de spi) & Middle third of main axis & Score (3-7) \\
\hline Angle between main axis and lateral branches & Middle third of tassel & Score $(1-9)$ \\
\hline Attitude of lateral branches (at lb) & In lower third tassel & Score $(1-9)$ \\
\hline Number of primary lateral branches (no plb) & Halfway anthesis & Score (1-9) \\
\hline Time of silk emergence ( $\mathrm{t}$ of se) & Upper ear & Score $(1-9)$ \\
\hline Anthocyanin coloration of silks (an col of s) & Upper ear & Score $(1,9)$ \\
\hline $\begin{array}{l}\text { Intensity of anthocyanin coloration of silks } \\
\text { (in of an col s) }\end{array}$ & Upper ear & Score (1-9) \\
\hline Anthocyanin coloration of sheath (an col sh) & Middle of plant & Score $(1-9)$ \\
\hline Anthocyanin coloration of internodes (an col inno) & Middle of plant & Score (1-9) \\
\hline $\begin{array}{l}\text { Length of main axis above lowest side branch } \\
\text { (le malb) }\end{array}$ & Watery ripe grain & Score $(1-9)$ \\
\hline $\begin{array}{l}\text { Length of main axis above upper side branch } \\
\text { (le maub) }\end{array}$ & Watery ripe grain & Score $(1-9)$ \\
\hline Width of blade (w of b) & Leaf of upper ear & Score $(1-9)$ \\
\hline Number of off types & & Numbers \\
\hline Length of peduncle (le of peduncle) & Upper ear & Score (1-9) \\
\hline Length of husk off the tip of the ear (le hu ti e) & Upper ear & Score (1-9) \\
\hline Ear length (e le) & Upper ear without husk & Score (1-9) \\
\hline Ear diameter (e di) & Middle of ear & Score $(1-9)$ \\
\hline Ear shape (e sh) & Hard grain & Score $(1-3)$ \\
\hline Ear number of rows (e no rows) & Middle of ear & Score (1-9) \\
\hline Type of grain (type g) & Middle third of ear & Score $(1-9)$ \\
\hline Colour of grain ( $\mathrm{col} \mathrm{g})$ & Hard grain & Score (1-9) \\
\hline Colouration of dorsal side of grain (col dsg) & Hard grain & Score $(1-9)$ \\
\hline Anthocyanin coloration of glumes of cob (an col gc) & Hard grain & Score $(1,9)$ \\
\hline $\begin{array}{l}\text { Intensity of anthocyanin coloration of glumes of cob } \\
\text { (in an col gc) }\end{array}$ & Hard grain & Score (1-9) \\
\hline
\end{tabular}

Scale adopted from UPOV (2009)

components for Longe $9 \mathrm{H}$ accounted for $22 \%$, $19 \%$ and $11.1 \%$, respectively (Table 6). The most important traits for discriminating the hybrids samples were angle between main axis and lateral branches, the attitude of lateral branches, time of silking, Anthocyanin colouration, anthocyanin colouration of anthesis, time of silking anthocyanin colouration of silks and density of spikelets.

The visualisation of PC scores for Longe $6 \mathrm{H}$ showed that different samples distributed separately in the two-dimension area, and agrodealer samples from Muhabura-45, Kigumba-44, Iganga-96, Bweyale-43, Masindi-(19, 20, 16, 102, 


\section{I.Y.A. MONIR et al.}

and 15) and Luwero-95 were grouped with the seed company sample, which represented $40.7 \%$ of the total number of the 27 samples. This implies that $50.3 \%$ of the samples were not grouped together with seed company reference samples, indicating that they were contaminated or not similar to the references.

Score plot of Longe $7 \mathrm{H}$ showed that, agrodealer samples from Iganga-(106, 115, 112, 107, 114, 27 and 30), Bukedea-42, Soroti-(66, 10 and 2) and Masindi-(105 and 113) were grouped with the reference sample from Seed Company-A; whereas samples from Iganga-27 were the only samples grouped with the second Seed SompanyB. The score plot of Longe 9H showed that only one agro-dealer's sample from Iganga-119 was grouped with the Seed Company's reference, which represented $33.3 \%$ of the total number of the samples 6 . This implies that the rate of variation from the Seed Companies was $66.7 \%$. The score plot of Longe $10 \mathrm{H}$ showed that the seed company sample had grouped alone as an outlier.

Cluster analysis of hybrids. Results of the cluster analysis based on Euclidean distance clustered hybrids into three to five main groups. Longe $10 \mathrm{H}$ samples fell into four groups, with a similarity level of $84 \%$. The first cluster included only one agro-dealer sample, which was the seed company's sample. The second cluster contained 47 agro-dealer samples, which were sub-grouped into three different groups. The third contained one agro-dealer sample; while the fourth group included two agro-dealer samples (Fig. 1).

Longe $9 \mathrm{H}$ clustered into four groups, with $81 \%$ level of similarity. The first group contained two agro-dealer samples, including the seed company's sample. The second group contained two agro-dealer samples; the third one contained one agro-dealer sample as well as the fourth group (Fig. 2).

Longe $7 \mathrm{H}$ clustered into four groups, with $85 \%$ level of similarity. The first group contained 17 agro-dealer samples, which included the seed company-A. The second group included one agro-dealer sample as well as the fourth group. While the third group contained three agro-dealer samples and a sample from seed company-B (Fig. $3)$. 
TABLE 4. Longe $6 \mathrm{H}$ eigenvectors, eigenvalues, the individual and cumulative percentage of variation explained by the first four principal components (PCs)

\begin{tabular}{|c|c|c|c|c|}
\hline Trait* & PC1 & PC2 & PC3 & PC4 \\
\hline $\mathrm{An} \mathrm{Col}$ & -0.05 & -0.14 & 0.05 & 0.29 \\
\hline Shpe $T$ & -0.25 & -0.22 & 0.07 & 0.07 \\
\hline Angle BS & -0.18 & -0.07 & 0.3 & 0.16 \\
\hline At of $B$ & -0.2 & -0.01 & 0.18 & -0.11 \\
\hline Degree Zig & -0.16 & 0.08 & 0.22 & -0.04 \\
\hline$A n \mathrm{Col} B R$ & 0.19 & -0.09 & 0.21 & 0.13 \\
\hline$T A n$ & 0.25 & -0.29 & 0.04 & 0.06 \\
\hline An Col BG & 0.22 & -0.22 & 0.23 & -0.1 \\
\hline An Col Gex & 0.22 & 0.22 & 0.14 & -0.14 \\
\hline An ColAnth & 0.18 & -0.15 & 0.2 & -0.19 \\
\hline De Spi & 0.07 & -0.13 & 0.02 & -0.06 \\
\hline Angle MI & 0.08 & 0.01 & 0.36 & 0.11 \\
\hline At of $L B$ & 0.03 & 0.11 & 0.37 & 0 \\
\hline No of $P L B$ & -0.21 & 0.23 & 0 & 0.2 \\
\hline$T$ of $S E$ & 0.25 & -0.29 & 0.02 & -0.06 \\
\hline An Col of S & 0.08 & -0.11 & -0.04 & 0.36 \\
\hline In of $\mathrm{An} \mathrm{Col} S$ & -0.09 & 0 & -0.03 & 0.43 \\
\hline An Col Sh & 0.1 & -0.21 & -0.18 & -0.26 \\
\hline An col InNO & 0.28 & -0.16 & -0.12 & 0.01 \\
\hline Le MALB & 0.17 & 0.13 & -0.08 & 0.14 \\
\hline LeMAUB & 0.18 & 0.03 & 0.05 & 0.23 \\
\hline Wof $B$ & -0.05 & 0.28 & -0.19 & 0.07 \\
\hline Le Peduncle & 0.02 & 0.25 & 0.15 & -0.14 \\
\hline Le HuTiE & -0.09 & -0.03 & 0.27 & -0.07 \\
\hline$E L e$ & 0.14 & 0.24 & -0.27 & -0.04 \\
\hline$E D i$ & 0.2 & 0.17 & 0.1 & 0.2 \\
\hline Ea Sh & 0.07 & 0.06 & 0.26 & 0.25 \\
\hline E No Rows & 0.27 & 0.15 & 0.01 & 0.02 \\
\hline Type G & -0.1 & 0.21 & 0.2 & -0.22 \\
\hline $\mathrm{Col} \mathrm{G}$ & 0.22 & 0.17 & 0.03 & -0.02 \\
\hline Col DSG & 0.2 & 0.26 & 0.01 & 0.06 \\
\hline $\mathrm{An} \mathrm{Col}$ GC & 0.22 & 0.22 & 0.14 & -0.14 \\
\hline $\ln \mathrm{An} \mathrm{Col} G \mathrm{G}$ & 0.17 & 0.02 & -0.1 & 0.25 \\
\hline Cumulative (\%) & 20 & 34 & 44.9 & 53.3 \\
\hline
\end{tabular}

*Traits corresponding to the underlined numbers are the most significant traits that contributed much of the variation in each PC

Longe $6 \mathrm{H}$ clustered into five main groups, with $84 \%$ similarity level. The first group included 19 agro-dealer samples, which included the seed company's sample. The second group contained one agro-dealer sample as well as the fifth group. The third group contained 2 agro-dealer samples, while the fourth group contained 3 agro-dealer samples (Fig. 4).

The study also estimated the percentage of off-types in each variety (the number of off-types' $\times 100$ per the total number of the samples). The results revealed that within the samples from agro-dealers there mixture of improved seed with grain. This was done possibly to increase the seed quantity and make more profit (Table 8).

\section{DISCUSSION}

This study gives a description of a system of Quality Control and Quality Assurance of hybrids which were released with a focus on the phenotypic data. We defined quality control as 
TABLE 5. Longe 7H eigenvectors, eigenvalues, the individual and cumulative percentage of variation explained by the first four principal components

\begin{tabular}{|c|c|c|c|c|}
\hline Trait* $^{*}$ & PC1 & PC2 & PC3 & PC4 \\
\hline An Col & 0.2 & -0.28 & -0.06 & 0.07 \\
\hline Shpe T & -0.04 & 0.11 & -0.05 & -0.15 \\
\hline Angle BS & 0.01 & -0.25 & 0.02 & -0.32 \\
\hline At of $B$ & 0.18 & 0.06 & 0.14 & -0.09 \\
\hline Degree Zig & -0.03 & 0.06 & 0 & -0.25 \\
\hline $\mathrm{An}$ Col BR & 0.1 & -0.13 & 0.09 & 0.31 \\
\hline TAn & -0.22 & -0.26 & 0.24 & -0.07 \\
\hline An Col BG & 0.09 & 0.02 & 0.2 & 0.31 \\
\hline An Col Gex & 0.04 & 0.29 & 0.16 & -0.04 \\
\hline An Col Anth & -0.11 & -0.02 & 0.02 & -0.17 \\
\hline De Spi & -0.06 & -0.33 & 0.23 & -0.16 \\
\hline Angle Ml & 0.3 & -0.04 & -0.2 & -0.02 \\
\hline At of LB & 0.3 & -0.15 & 0.06 & -0.17 \\
\hline No of PLB & 0.04 & 0.3 & -0.23 & 0.03 \\
\hline T of SE & -0.19 & -0.28 & 0.21 & -0.1 \\
\hline An Col of S & -0.2 & 0.06 & -0.34 & 0.22 \\
\hline In of An Col S & 0.23 & -0.05 & -0.06 & 0.11 \\
\hline An Col Sh & 0.2 & 0.07 & -0.08 & -0.03 \\
\hline An col InNO & 0.12 & -0.2 & 0.02 & -0.04 \\
\hline Le MALB & 0.27 & 0.18 & -0.03 & -0.24 \\
\hline LeMAUB & 0.28 & -0.09 & -0.16 & -0.12 \\
\hline W of $B$ & 0.12 & 0 & -0.13 & -0.35 \\
\hline Le Peduncle & -0.06 & 0.08 & -0.02 & -0.3 \\
\hline Le Hu Ti E & -0.12 & 0.04 & -0.2 & -0.09 \\
\hline E Le & 0.07 & 0.23 & 0.21 & -0.3 \\
\hline E Di & 0.21 & -0.12 & -0.29 & -0.03 \\
\hline Ea Sh & -0.04 & -0.2 & -0.34 & -0.03 \\
\hline E No Rows & 0.25 & -0.21 & -0.09 & 0.07 \\
\hline Type G & -0.23 & -0.02 & -0.15 & -0.23 \\
\hline Col G & 0.26 & 0.15 & 0.25 & 0.1 \\
\hline Col DSG & 0.24 & -0.02 & 0.28 & 0 \\
\hline An Col GC & 0.04 & 0.29 & 0.16 & -0.04 \\
\hline In An Col GC & -0.12 & -0.02 & 0.01 & 0.17 \\
\hline Cumulative (\%) & 19 & 32.4 & 42.3 & 51.1 \\
\hline
\end{tabular}

*Traits corresponding to the underlined numbers are the most significant traits that contributed much of the variation in each PC

steps taken to monitor and control the quality of a product as it is produced, while quality assurance is defined as a post-production review of product quality (Laurie et al., 2010). In this study, 33 phenotypic traits were used to characterise a set of 120 samples of four maize hybrids (Longe $10 \mathrm{H}, 9 \mathrm{H}, 7 \mathrm{H}$, and $6 \mathrm{H}$ ) collected from agro-dealers in 13 districts and three from seed companies in Uganda.

Analysis of variance showed that among the test materials only Longe $9 \mathrm{H}$ had no significant difference within traits, but the others had some levels of significant differences (Table 3). This meant that among the samples of Longe hybrids, only those of Longe $9 \mathrm{H}$ appeared to be related to each other hence the level of quality of Longe $9 \mathrm{H}$ compared to other hybrids was good. There were more traits which had significant differences within the same variety and this meant that the samples collected for that particular variety had low quality. These results suggest that the level of variation/contamination is higher in Longe $10 \mathrm{H}$, followed by Longe $6 \mathrm{H}$ and Longe $7 \mathrm{H}$; whereas Longe $9 \mathrm{H}$ appeared as a pure variety. 
TABLE 6. Longe $9 \mathrm{H}$ eigenvectors, eigenvalues, the individual and cumulative percentage of variation explained by the first four principal components

\begin{tabular}{|c|c|c|c|c|}
\hline Trait* $^{*}$ & PC1 & PC2 & PC3 & PC4 \\
\hline An Col & -0.10 & -0.15 & -0.33 & 0.08 \\
\hline Shpe T & -0.06 & -0.17 & 0.19 & -0.33 \\
\hline Angle BS & -0.15 & -0.26 & 0.08 & -0.02 \\
\hline At of $B$ & -0.24 & -0.09 & 0.01 & -0.23 \\
\hline Degree Zig & 0.25 & -0.01 & 0.02 & -0.11 \\
\hline An Col BR & 0.16 & 0.17 & 0.17 & 0.17 \\
\hline TAn & 0.24 & 0.11 & 0.05 & -0.17 \\
\hline An Col BG & -0.15 & -0.06 & 0.24 & 0.16 \\
\hline An Col Gex & 0.24 & -0.17 & 0.03 & -0.07 \\
\hline An Col Anth & 0.01 & -0.09 & 0.36 & -0.16 \\
\hline De Spi & 0.18 & 0.18 & -0.01 & 0.31 \\
\hline Angle MI & 0.00 & -0.30 & 0.11 & 0.25 \\
\hline At of LB & 0.00 & -0.33 & 0.08 & 0.21 \\
\hline No of PLB & 0.22 & -0.12 & -0.16 & -0.02 \\
\hline T of SE & -0.01 & 0.35 & 0.03 & -0.14 \\
\hline An Col of S & 0.05 & 0.16 & -0.34 & 0.06 \\
\hline In of An Col S & 0.11 & -0.10 & -0.24 & -0.10 \\
\hline An Col Sh & -0.20 & -0.14 & 0.12 & 0.14 \\
\hline An col InNO & -0.24 & 0.05 & 0.16 & 0.00 \\
\hline Le MALB & -0.23 & 0.08 & 0.00 & -0.26 \\
\hline LeMAUB & -0.22 & 0.10 & 0.03 & -0.25 \\
\hline W of $B$ & -0.04 & -0.16 & -0.28 & 0.28 \\
\hline LePeduncle & 0.18 & 0.22 & 0.15 & -0.05 \\
\hline Le Hu Ti E & -0.20 & 0.09 & 0.05 & 0.26 \\
\hline E Le & -0.10 & -0.20 & -0.26 & -0.21 \\
\hline E Di & 0.13 & -0.30 & 0.05 & 0.00 \\
\hline Ea Sh & 0.15 & 0.22 & 0.06 & 0.22 \\
\hline E No Rows & 0.20 & -0.09 & 0.09 & -0.18 \\
\hline Type G & 0.21 & 0.02 & 0.26 & -0.01 \\
\hline Col G & 0.24 & -0.16 & 0.00 & -0.09 \\
\hline Col DSG & 0.25 & -0.13 & -0.04 & -0.05 \\
\hline An Col GC & 0.24 & -0.17 & 0.03 & -0.07 \\
\hline In An Col GC & -0.10 & 0.36 & 0.18 & 0.09 \\
\hline Cumulative \% & 40.70 & 62.70 & 81.70 & 92.80 \\
\hline
\end{tabular}

*Traits corresponding to the underlined numbers are the most significant traits that contributed much of the variation in each PC

Results from the present study also demonstrate the presence of high phenotypic differences between different seed sources of four hybrids.

During hybrid maize seed production, maintenance of varietal purity and confirmation of the identity of the same hybrids collected from different locations are important quality control functions in the maize seed industry. These functions have become more critical due to the reports on prevailing fake seed on the market and counterfeits. In most seed industries, the principal causes of large variation in same samples or stocks originating from the same hybrid but sampled at a different level of value chain may be attributed to (a) issues (quality) with the parent inbred lines which were used to form the variety. Significant changes in the makeup of a germplasm may affect performance, and in the worst case result in the distribution of wrong hybrids or hybrids (Semagn et al., 2012). (b) mislabeling of the seed lot; for example, in Longe $10 \mathrm{H}$, the seed 
TABLE 7. Longe $10 \mathrm{H}$ eigenvectors, eigenvalues, the individual and cumulative percentage of variation explained by the first four principal components

\begin{tabular}{|c|c|c|c|c|}
\hline Trait* $^{*}$ & PC1 & PC2 & PC3 & PC4 \\
\hline An Col & -0.09 & -0.14 & 0.09 & -0.24 \\
\hline Shpe T & 0.11 & 0.05 & -0.14 & 0.09 \\
\hline Angle BS & 0.19 & 0.17 & 0.03 & -0.04 \\
\hline At of B & 0.22 & 0.04 & 0.00 & 0.23 \\
\hline Degree Zig & -0.10 & 0.09 & 0.13 & 0.18 \\
\hline An Col BR & 0.23 & -0.06 & 0.08 & -0.03 \\
\hline TAn & -0.33 & 0.17 & -0.11 & 0.18 \\
\hline An Col BG & -0.09 & -0.01 & 0.08 & 0.26 \\
\hline An Col Gex & -0.10 & 0.07 & 0.39 & 0.00 \\
\hline An Col Anth & 0.12 & -0.26 & 0.18 & 0.18 \\
\hline De Spi & -0.01 & -0.38 & 0.07 & 0.07 \\
\hline Angle MI & 0.34 & 0.07 & -0.14 & -0.11 \\
\hline At of LB & 0.27 & 0.10 & -0.20 & -0.04 \\
\hline No of PLB & 0.08 & -0.19 & 0.08 & -0.34 \\
\hline T of SE & -0.37 & 0.12 & -0.10 & 0.20 \\
\hline An Col of S & 0.09 & 0.29 & 0.00 & -0.02 \\
\hline In of An Col S & 0.34 & -0.11 & 0.13 & 0.00 \\
\hline An Col Sh & -0.05 & -0.09 & -0.08 & -0.10 \\
\hline An col InNO & -0.11 & -0.25 & 0.12 & -0.17 \\
\hline Le MALB & 0.13 & 0.33 & 0.26 & -0.07 \\
\hline Le MAUB & 0.19 & 0.32 & 0.13 & -0.07 \\
\hline W of $B$ & 0.15 & -0.04 & 0.28 & 0.09 \\
\hline Le Peduncle & 0.10 & 0.26 & 0.09 & 0.16 \\
\hline Le Hu Ti E & 0.04 & 0.18 & -0.13 & 0.16 \\
\hline E Le & 0.00 & 0.10 & 0.28 & 0.01 \\
\hline E Di & 0.23 & -0.14 & 0.10 & 0.20 \\
\hline Ea Sh & 0.18 & -0.09 & -0.23 & 0.01 \\
\hline E No Rows & 0.05 & -0.26 & 0.18 & 0.26 \\
\hline Type G & 0.09 & -0.06 & -0.20 & 0.30 \\
\hline Col G & -0.08 & 0.08 & -0.05 & -0.48 \\
\hline Col DSG & 0.07 & 0.09 & 0.12 & -0.04 \\
\hline An Col GC & -0.10 & 0.07 & 0.39 & 0.00 \\
\hline In An Col GC & -0.11 & 0.11 & 0.22 & 0.00 \\
\hline Cumulative (\%) & 15.10 & 23.80 & 32.00 & 39.10 \\
\hline
\end{tabular}

*Traits corresponding to the underlined numbers are the most significant traits that contributed much of the variation in each PC

TABLE 8. Percentage off types within the field

\begin{tabular}{lccc}
\hline Hybrids & Number of plants & Number of off-types & $\%$ \\
\hline Longe $10 \mathrm{H}$ & 1285 & 68 & 5.3 \\
Longe $9 \mathrm{H}$ & 54 & 3 & 5.6 \\
Longe $7 \mathrm{H}$ & 391 & 25 & 6.4 \\
Longe $6 \mathrm{H}$ & 487 & 41 & 8.5 \\
\hline
\end{tabular}




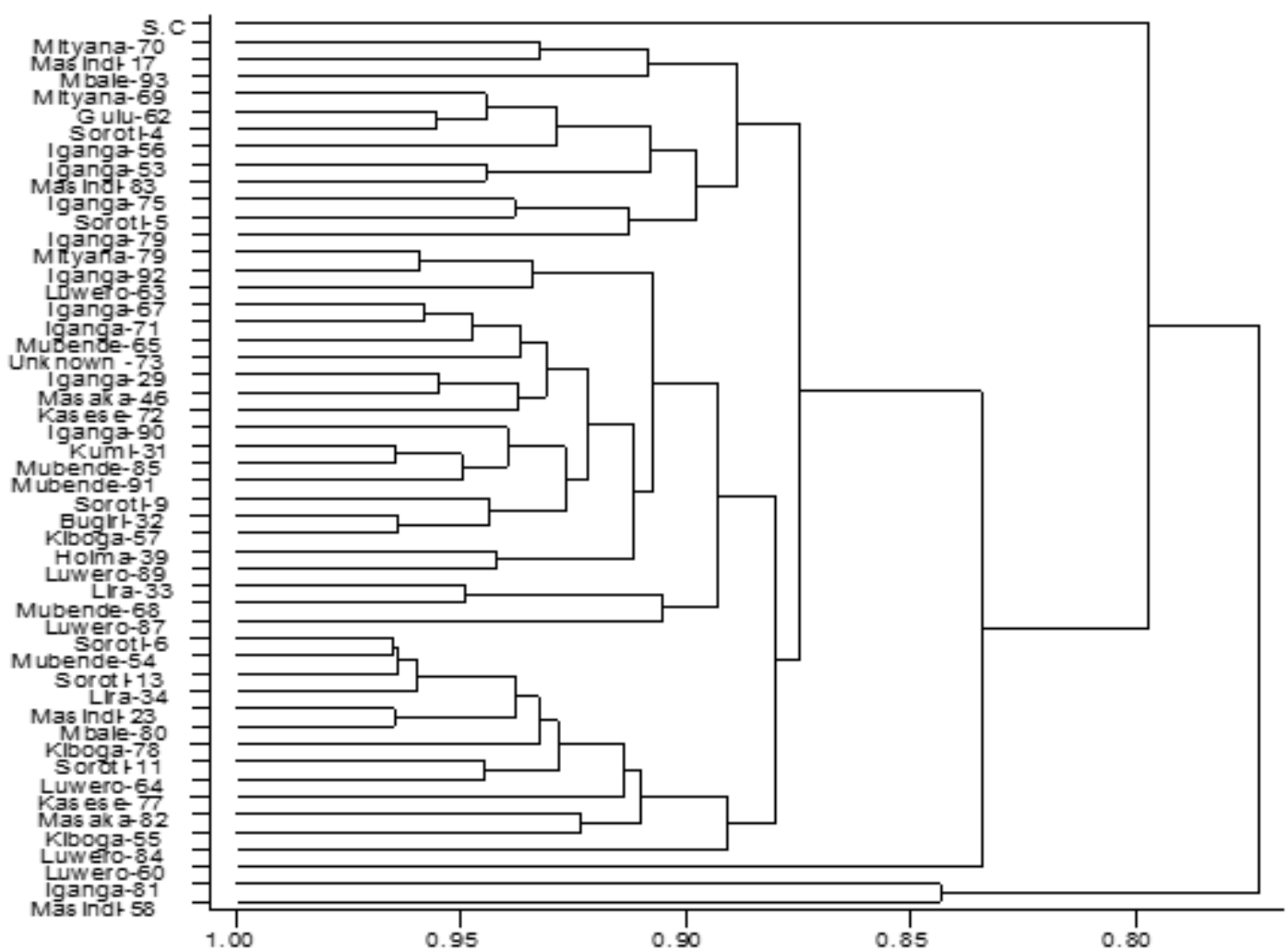

Figure 1. Longe 10H Dendrogram, based on 34 phenotypic traits using Euclidean distance matrix. *districts are indicted of the agrodealers

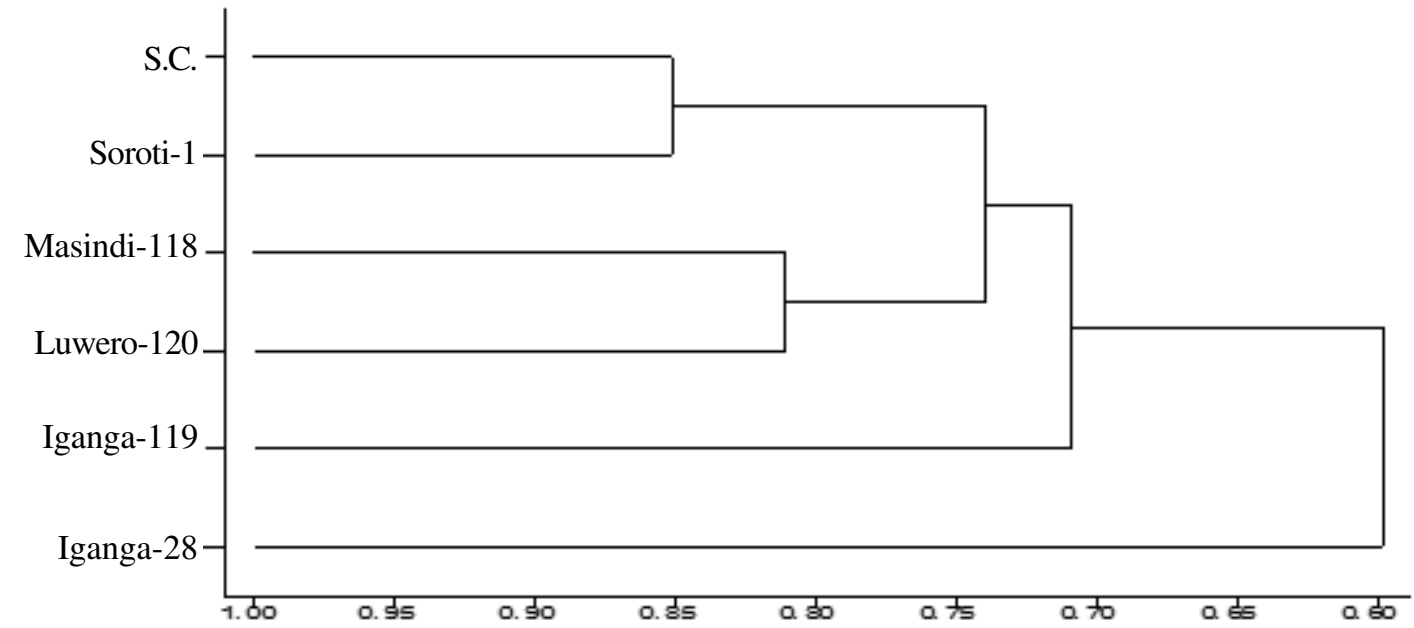

Figure 2. Longe 9H Dendrogram, based on 34 phenotypic traits using Euclidean distance matrix. *agro-dealers are represented by districts 


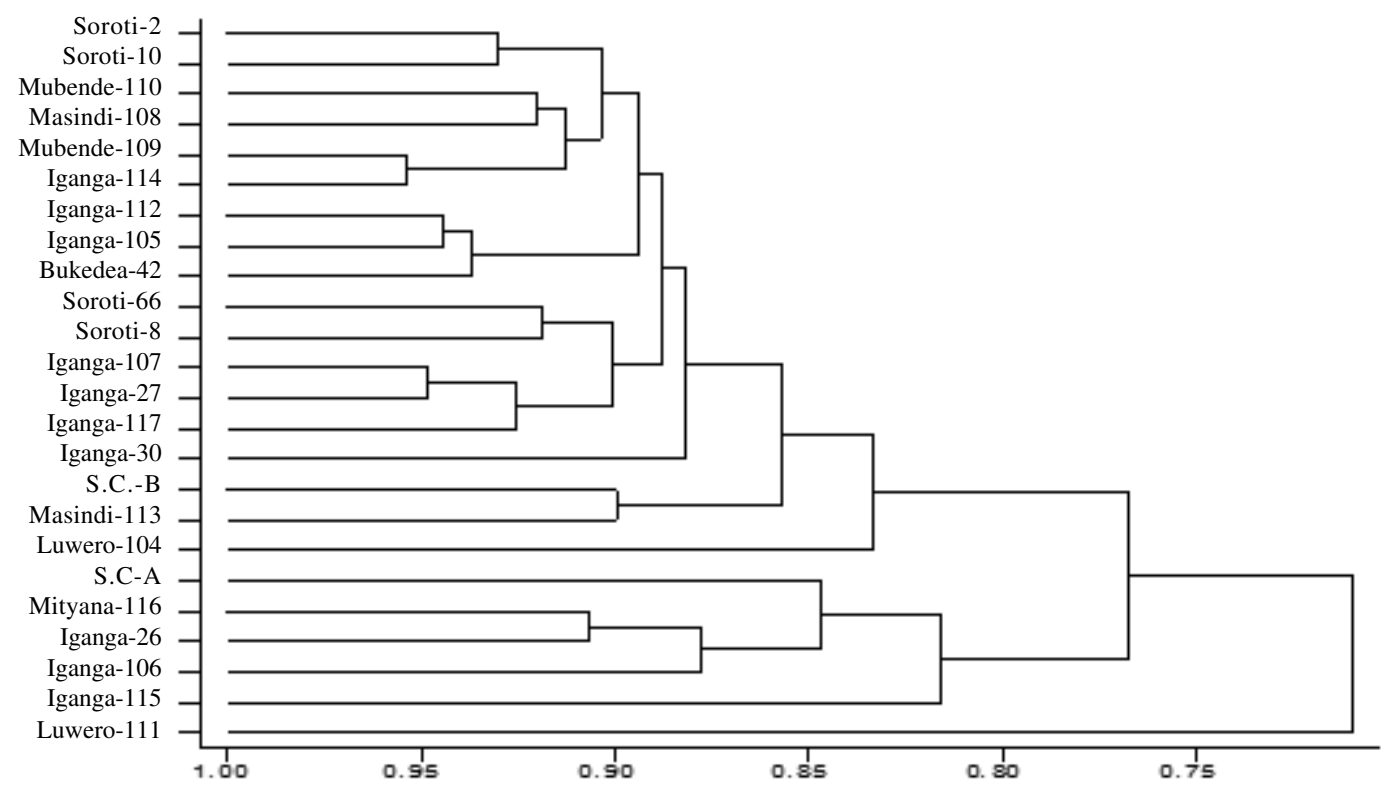

Figure 3. Longe 6H Uendrogram, based on 34 phenotypıc traits using tuclidean dıstance matrıx. "agro-dealers are represented by districts.

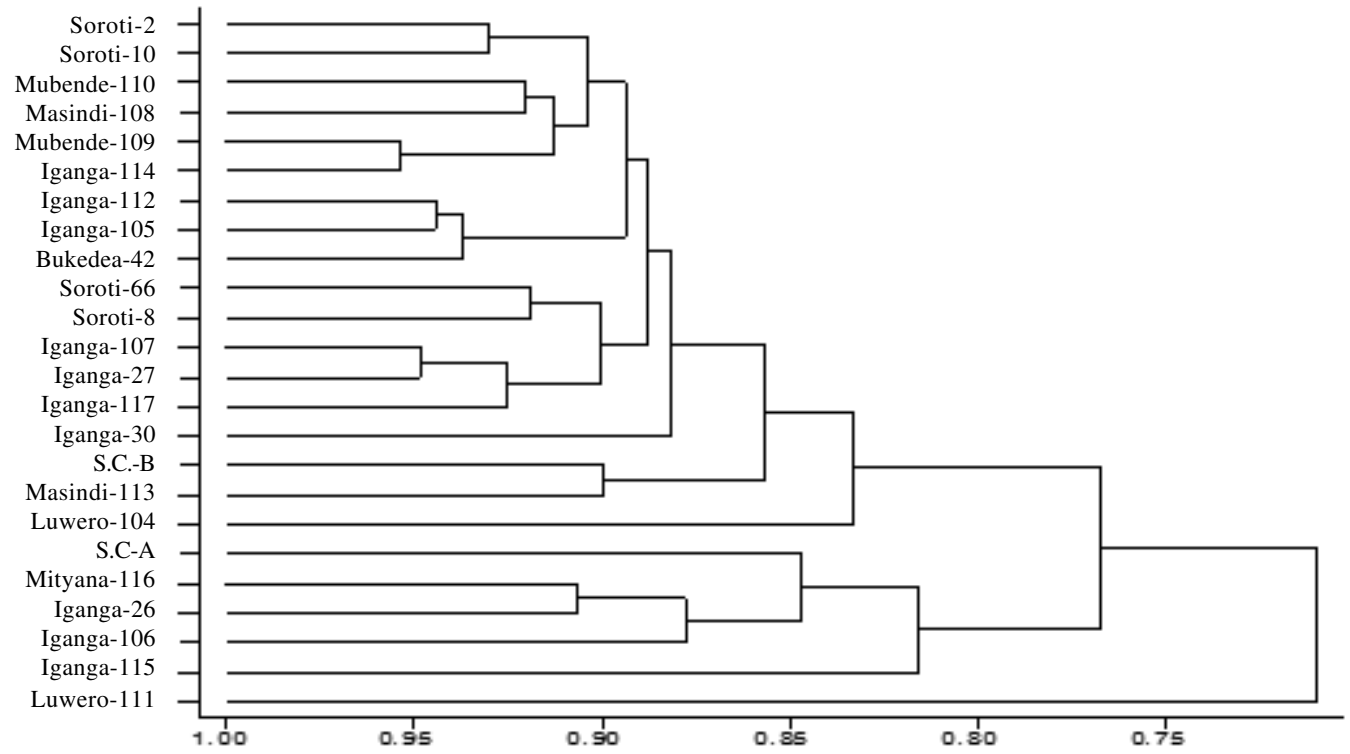

Figure 4. Longe 7H Dendrogram, based on 34 phenotypic traits using Euclidean distance matrix. *agro-dealers are represented by districts. 
company sample had grouped alone as an outlier. This suggests that the seed company misspackaged the seeds (packaging seeds of another variety in Longe $10 \mathrm{H}$ package) during the seed processing. (c) difference in seed lots; another cause of source of variation within the same hybrid can be attributed to difference in outgrower's seed lots. Seed companies tend to contract different out-growers for bulking their certified seeds. These are backstopped but the seed companies to ensure seed quality. Different agro-dealers within the same districts may be supplied with different lots of same hybrids.

Quality control is essential for seed regulations in any seed system. Seed quality control has two components, seed certification and seed testing (Tripp and Louwaars, 1998). Seed certification verifies the quality of seed; it provides assurance that seed is of a specified variety and is of acceptable genetic purity (Tripp and Louwaars, 1998). Seed testing examines various seed quality parameters, such as germination capacity, analytical purity, and pathogen levels. The results of these tests are usually considered by the certification agency before issuing a certification label (Tripp and Louwaars, 1998). Therefore, seed certification in its more general sense, refers to both the genetic and other qualities of seed, but the phenotypic distinction is very important.

The application of PCA and cluster analysis showed that combinations of these traits, which offer effective means for modeling and classifying different samples. The interpretation of the results of PCA is usually carried out by visualisation of its PC scores (Zhang et al., 2012). The results obtained from the Score plot of Longe $7 \mathrm{H}$ suggest variation between the seed companies' samples, which also might contribute to the variation within agro-dealers' seeds. This might be because seed companies contract farmers to grow/multiply seed, mostly under rain-fed conditions, thereby exposing the crop to variable rainfall conditions (Langyintuo, 2004). Additionally, the grower might face difficulty in achieving isolation distances of $200-400 \mathrm{~m}$ to ensure genetic purity and seed quality (Augustine et al., 2009). For example, Longe $7 \mathrm{H}$ reference samples from seed companies were expected to cluster together, but was not the case, hence the purity was compromised. This result suggests that the seed company's routine activities contributed to the different variations, by selling different versions of seed (seed with different lot numbers) to the agro-dealer. Moreover, it might be because of the agro-dealer or the seed company agent's problems such as lack of knowledge on varietal characteristics, lack of credibility on the part of some agents, adulteration of seed, and poor storage facilities.

From Cluster analysis, Longe $10 \mathrm{H}$ was the variety with the highest level of contamination, with almost $90.5 \%$ of agro-dealer samples contaminated. In contrast, Longe $6 \mathrm{H}$ had the lowest rate of contamination with almost $20.6 \%$ of the agro-dealer samples contaminated. This might be because of the high demand of Longe $10 \mathrm{H}$.

Agro-dealers' samples from Iganga, Masindi, Luwero, Soroti, Bukedea and Muhabura showed high seed quality compared with the seed companies for the four hybrids under study. Samples from Lira, Hoima, Mubende, Mityana, Gulu, Kiboga, and Bugiri showed a high rate of variation. However, samples from some districts were mixed (quality seed and contaminated). For this, it is hard to distinguish districts with $100 \%$ agro-dealers' seed quality. Therefore, more analysis was needed based on the phenotypic data. All these different analyses supported the presence of variation/contamination within hybrid seeds under study at agro-dealer level. Therefore, regular monitoring and enforcement of seed regulation policies along the value chain can improve the formal seed supply system.

\section{CONCLUSION}

This study has revealed the existence of varying levels contamination of released hybrids along the seed value chain in the Uganda seed market. Variations among same hybrids collected from different agro-dealers in different districts may be attributed to seed mixing, mislabeling of hybrids and variation in seed lots. Quality control measure within different seed lots from different out-growers should be emphasized and premium price should be given to ensure quality. Also, molecular markers may be useful in discriminating among these and also confirm the phenotypic 
diversity observed. There is need to strengthen quality control sector if improved productivity at farmer level is to be realised.

\section{ACKNOWLEDGEMENT}

This research was supported by Government of Uganda through the Agricultural Technology and Agribusiness Advisory Services (ATAAS) project and the Bill and Melinda Gates Foundation through Piloting project; Use of Molecular Markers to Enhance Quality Assurance and Control in the Seed Value Chain in Uganda. We thank Professor Scott A. Jackson and Dr. Dan Makumbi for helpful comments and suggestions on the manuscript. We thank Lucy Billings from IFPRI for sharing some of the materials from agro-dealers. We appreciate all $\mathrm{NaCRRI}$ staff for assistance with data collection at the experimental site.

\section{REFERENCES}

Barnett, C., Chisvo, M., and Pinto, Y. 2011. Country case studies on the pass value chain strategy /Approach And Its Impact / Effect On Smallholder Farmer Prepared by/ EAST AFRICASYNTHESIS REPORT, (January).

Begum, T. and Kumar, D. 2011. Usefulness of morphological characteristics for DUS testing of jute (Corchorus olitorius L. and $C$. capsularis L.). 9: 11.

Beshir, B. 2011. Open pollinated maize seed systems linkages through farmer research group in Central Rift Valley of Ethiopia. Farmers' Access to Seed. pp. 43.

Chanda, R., Mukanga, M., Mwala, M., Osiru, D. S., and Macrobert, J. 2014. A comparative analysis of distinctness, uniformity and stability ( DUS ) data in discriminating selected Southern African maize ( Zea mays L.) inbred lines. African Journal of Agricultural Research 9(41): 3056-3076. http:/ /doi.org/10.5897/AJAR2014.8755

FNSU-UDS. 2011. Three country ( Burkina Faso, Ghana and Mali ) case studies on the PASS Value Chain Strategy / Approach and its Effect on Smallholder Farmer Yields in Africa. Draft report Submitted to Alliance for a Green Revolution in Africa. Food and Nutrition
(April). Retrieved from http://www.mendeley. com/research/three-country-burkina-fasoghana-mali-case-studies-pass-value-chainstrategy-approach-effect-smallho/

Hung, H.Y., Browne, C., Guill, K., Coles, N., Eller, M., Garcia, A., Lepak, N., Melia-Hancock, S., Oropeza-Rosas, M., Salvo, S., Upadyayula, N., Buckler, E. S., Flint-Garcia, S., Mcmullen, M. D., Rocheford, T. R. and Holland, J. B. 2012. The relationship between parental genetic or phenotypic divergence and progeny variation in the maize nested association mapping population. Heredity 108: 490-499.

Ignjatoviæ-Miciæ, D., Ristiæ, D., Babiæ, V., Andjelkoviæ, V., Markoviæ, K. and Vanèetoviæ, J. 2013. Genetic assessment of maize landraces from former Yugoslavia. Genetika 45(2): 405-417. http://doi.org/ 10.2298/GENSR1302405I

Langyintuo, A.S. 2004. Challenges of the Seed Sector of Southern Africa. International Maize and Wheat Improvement Center (CIMMYT) Report, Harare, Zimbabwe, 39. Retrieved from $<$ www.cimmyt.org/gis/rfseedsafrica/>

Laurie, C.C., Doheny, K.F., Mirel, D.B., Pugh, E.W., Bierut, L.J., Bhangale, T., Boehm, F., Caporaso, N. E., Cornelis, M. C., Edenberg, H. J., Gabriel, S. B., Harris, E. L., Hu, F. B., Jacobs, K. B., Kraft, P., Landi, M. T., Lumley, T., Manolio, T. A., Mchugh, C., Painter, I., Paschall, J., Rice, J. P., Rice, K. M., Zheng, X., Weir, B. S. and For The, G.I. 2010. Quality control and quality assurance in genotypic data for genome-wide association studies. Genetic Epidemiology 34: 591-602.

Law, J., Anderson, S., Jones, E., Nelson, B., Mulaosmanovic, E., Hall, B. and Smith, J. 2011. Approaches to improve the determination of eligibility for plant variety protection: I evaluation of morphological characteristics. Maydica 56: 113-131.

Mubangizi, E., Ntamu, D.N., Mwesigwa T.W. and Thijssen, M. 2012. ISSD Briefing Note September 2012 Uganda Seed Sector Assessment. ISSD Africa, (September) 1-7.

Mrutu, B.A. 2015. Assessment of seed genetic purity of hybrid maize variety UH6303 in southern highlands of Tanzania by random amplified polymorphic DNA (RAPD) markers. 
African Journal of Agricultural Research 10: Tripp, R. and Louwaars, N. 1998. Seed regulation: 2911-2918.

Semagn, K., Beyene, Y., Makumbi, D., Mugo, S., Prasanna, B.M., Magorokosho, C. and Atlin, G. 2012. Quality control genotyping for assessment of genetic identity and purity in diverse tropical maize inbred lines. Theoretical and Applied Genetics 125: 1487 501. choices on the road to reform. Food Policy, 22: 433-446.

UPOV. 2009. Guidelines for the conduct of tests for distinctness, uniformity, and stability; maize. TG/2/7. UPOV, Geneva, Switzerland.

Ward, J.H. 1963. Hierarchical grouping to optimize an objective function, Journals American Statistical Association 58:236-244.

Smýkal, P., Horáèek, J., Dostálová, R. and Hýbl, M. 2008. Variety discrimination in pea (Pisum sativum L.) by molecular, biochemical and morphological markers. Journal of Applied Zhang, X., Liu, F., He, Y. and Li, X. 2012. Application of hyperspectral imaging and chemometric calibrations for variety discrimination of maize seeds. Sensors 12(12): 17234-17246. http://doi.org/10.3390/ s121217234 